\title{
POLITIK DAN RELIGIOSITAS
}

Oleh: Frederikus Dhedhu

\begin{abstract}
Abstrak:
Artikel ini bertujuan menemukan sisi religiositas dalam politik. Hasilnya yang diperoleh bahwa dunia politik Indonesia sedang beranjak meninggalkan "rumah religiositasnya". Gerakan meninggalkan rumah religiositas menyebabkan lepasnya kontrol atas politik oleh religiositas yang sesungguhnya merupakan instansi yang membentengi para elit politik dari dosa-dosa politisnya. Pada saat para elit politik memisahkan diri dari kontrol religiositas pada saat itu aktivitas politik kehilangan makna dan relevansinya.
\end{abstract}

Kata kunci: Politik, Religiositas, Etika, Martabat manusia.

\section{PENGANTAR}

uasana kehidupan berbangsa dan bernegara akhir-akhir ini agak mencemaskan. - Pilar-pilar penyangga kehidupan berbangsa dan bernegara sedang diganggu oleh kelompok-kelompok radikalis. Sementara itu para elit politik yang memiliki kapasitas dan otoritas tertentu, yang sebenarnya harus menjadikan mereka figur-figur strategis menuju Indonesia baru, justru terjebak dalam kancah perseteruan politik yang tak berujung. Kecemasan tersebut menjadi lebih beralasan lagi tatkala perseteruan politik para elit politik tidak pernah menyentuh substansi persoalan dan keprihatinan masyarakat tetapi hanya sekedar menjaga agar kendaraan politiknya tetap berjalan sambil mengeksploitasi sentimen keagamaan untuk mendapat masa pendukung.

Fenomena ini mulai terasa saat menjelang Pemilihan Umum (selanjutnya disingkat Pemilu) dan akan tetap terasa jika para elit politik tidak mau bertobat dan terus berkubang dalam dosa-dosa politisnya. Bukan merupakan rahasia lagi bahwa dalam diri elit politik terdapat ambivalensi sikap politik. Pada saat suara rakyat dibutuhkan untuk memuluskan langkah menuju satu posisi politik tertentu, segala pidato dan kampanye selalu berorientasi pada kepentingan rakyat. Namun ketika rakyat telah memberikan suara dan berhasil menempatkannya pada satu posisi politik tertentu, segala pidato dan kampanye yang pada mulanya merujuk pada kepentingan masyarakat menjadi sangat relatif. Titik referensi perjungan para elit politik mulai bergeser dari kepentingan rakyat ke kepentingan pribadi dan golongan. ${ }^{1}$ Dunia politik dan aktivitas politik diredusir menjadi urusan privat tanpa komitmen sosial. Inilah tindakan pemiskinan dan pengkhianatan terhadap hakekat politik itu sendiri. Tindakan pemiskinan dan pengkhianatan kian parah ketika dunia politik dengan angkuhnya berpaling dari basis religiositas.

\section{POLITIK}

\subsection{Pengertian}

${ }^{1}$ Pit Go, dkk, Etos dan Moralitas Politik (Yogyakarta: Kanisius, 2004), hlm. 24. 
Politik berasal dari kata Yunani politikos: warga negara; polis: kota, negara; politea: kewargaan. ${ }^{2}$ Dari arti etimologis tersebut, politik dapat didefinisikan sebagai: "Segala usaha dan kegiatan warga untuk menata, berkonsensus menentukan "a rational ordering of society" sehingga tata sosial menjadi lebih adil, sejahtera untuk hidup bersama dengan dasar saling menghormati antarwarga atas dasar hormat pada harkat kemanusiaanya. ${ }^{3}$ Definisi di atas menegaskan unsur hakiki dalam politik secara sangat positip. Dengan demikian ketakutan tentang politik sebagai sesuatu yang kotor dan sarat penipuan serta manipulasi sebenarnya tidak memilki alasan yang kuat. Politik dalam dirinya sendiri sangat positif. Politik menjadi kotor ketika politikus tidak berorientasi pada kesejahteraan bersama tetapi pada kepentingan pribadi dan golongan.

\subsection{Politik yang Bermartabat}

\subsubsection{Politik demi Bonum Commune}

Untuk sampai pada pemahaman tentang politik yang berorientasi pada kesejahteraan umum, baiklah direfleksikan beberapa pertanyaan berikut: Mengapa para elit politik terjerat kasus korupsi? Mengapa terjadi politik uang dalam suksesi kepemimpinan di Indonesia? Mengapa kampanye politik di Indonesia bukan saat uji kebijakan dan program tetapi saat untuk saling menghina dan mengancam? Apa yang sedang menggerogoti para elit politik, sehingga terus-menerus terperangkap dalam kesalahan politis, sehingga dalam banyak kebijakan tidak mengenal kalkulasi dan konsekuensi politis sehingga harus dibayar dengan harga yang sangat mahal?

Pertanyaan-pertanyaan di atas mengisyaratkan bahwa ada sesuatu yang hilang dalam aktivitas politik para politisi. Nampaknya politik dengan intensi yang kuat dan mendalam terhadap kesejahteraan bersama belum menjadi arus dasar yang mengarahkan para politisi. Para politisi masih dikuasai oleh tawaran uang. Tendensi komersialisasi jabatan masih sangat kuat. Ketika jabatan diperjual-belikan, maka pejabat akan berpikir tentang bagaimana mendapatkan kembali uang yang sudah dikeluarkan untuk memperoleh jabatan tersebut. Kondisi tersebut membuat membuat opsi pada kesejahteraan umum menjadi sangat lemah.

Karena itu perlu dibangun kesadaran baru bahwa religiositas dengan muatan iman, kebenaran dan keadilan perlu menjadi fondamen aktivitas politik. Lebih dari itu dimensi religius dalam dunia politik harus tetap dipromosikan agar tetap menjadi unsur yang memurnikan dunia politik, baik pada tataran konseptual maupun pada tataran realisasinya. Elit politik yang menjadikan religiositas sebagai sumber inspirasi aktivitas politiknya bakal menjadi elit politik yang berkualitas karena mampu berdiri pada pusat-pusat penderitaaan rakyat dan terlibat dalam upaya-upaya konkrit penguatan dan pemberdayaan masyarakat demi kesejahteraan bersama. Kesejahteraan bersama merupakan alasan keberadaan otoritas politik. ${ }^{4}$

\subsubsection{Politik demi Martabat Manusia}

Pembicaraan tentang politik tidak bisa dipisahkan dari pembicaraan tentang manusia. Manusia adalah gambaran Allah. Karena itu manusia memiliki martabat yang luhur dan patut dihargai. Politik yang benar adalah politik yang menjunjung tinggi

\footnotetext{
${ }^{2}$ Lorens Bagus, Kamus Filsafat (Jakarta: Gramedia, 1996), hlm. 857.

${ }^{3}$ Muji Sutrisno, Humanisme, Krisis, Humanisasi (Jakarta: Obor, 2001), hlm. 39.

${ }^{4}$ Piero Sapienza, La Politica che non C'e, Da Cittadini attivi nella Pollis (Vaticana: Libreria Editrice, 2009), hlm. 133.
} 
martabat manusia. Seringkali kebijakan politik mengangkangi martabat manusia. Argumentasi politik pembangunan tidak terfokus pada martabat manusia tetapi pada hal-hal lain yang sifatnya sekunder.

Harus disadari bahwa ada nilai pokok yang menjadi fokus kebijakan politik yakni martabat manusia sebagai subyek, solidaritas dan keberpihakan pada yang lemah. Penataan hidup bermasyarakat tidak mungkin terlaksana dengan benar kalau tidak berdasarkan pengertian yang tepat tentang manusia sebagai pribadi. Manusia bukanlah komoditi, aset atau modal yang boleh dipermainkan dan diperlakukan sewenang-wenang. Maka upaya komoditisasi manusia dalam politik pembangunan harus diatasi dan dilawan. ${ }^{5}$

\section{RELIGIOSITAS}

2.1. Pengertian

Dalam arti luas religiositas merupakan keseluruhan pengalaman manusia di dalamnya manusia yakin bahwa dia disapa oleh yang ilahi. Jawaban manusia atas sapaan yang Ilahi adalah iman. Di atas fundamen iman itulah manusia menata hubungannya dengan yang Ilahi. Dalam relasi tersebut, manusia menyerahkan diri sepenuhnya dan mengarahkan hidupnya agar mendapat arti dari yang Ilahi. ${ }^{6}$

\subsection{Ekspresi Religiositas}

Pribadi yang memiliki religiositas yang kuat dan mendalam akan menampakan beberapa ciri berikut ini dalam hidupnya ${ }^{7}$ :

a. Memiliki kemampuan untuk menghayati nilai-nilai kehidupan serta mampu memaknai pengalaman hidup. Mampu mengatasi kenikmatan-kenikmatan sesaat dan mampu memaknai semua pengalaman hidup secara positip.

b. Memiliki citarasa hirarki nilai obyektip yang melahirkan visi dan perspektif hidup baru. Nilai-nilai obyektip misalnya nilai iman dan nilai moral tetap menjadi acuan dalam bersikap dan bertindak.

c. Memiliki rasa religius dan kemampuan berkontak dengan Tuhan. Perkembangan ilmu pengetahuan dan teknologi tidak serta merta membuatnya memutlakkan otonomi pribadi tetapi tetap melihat hidup dan pergumulannya dalam bingkai penyelenggaraan Ilahi.

d. Memilki kemampuan untuk membaktikan diri secara radikal bagi Tuhan dan sesama. Tawaran uang dan kuasa, tidak membuatnya dengan mudah mengkhianati profesinya tetapi dengan setia membaktikan seluruh hidupnya bagi Tuhan dan sesama.

\section{POLITIK DAN RELIGIOSITAS}

${ }^{5}$ B.Kieser, Agama dan tantangan Ketulusan: Tulus seperti Merpati dan Cerdik seperti Ular (Yogyakarta: Kanisius, 2001), hlm. 23.

${ }^{6}$ Muji Sutrisno, Ide-Ide Pencerahan (Jakarta: Obor, 2004), hlm. 260.

${ }^{7}$ Mardi Prasetya, Unsur-unsur Hakiki dalam Pembinaan (Yogyakarta: Kanisius, 2000), hlm. 34-37. 
Pengalaman membuktikan bahwa dunia politik Indonesia sedang beranjak meninggalkan "rumah religiositasnya". Gerakan meninggalkan rumah religiositas menyebabkan lepasnya kontrol atas politik oleh religiositas yang sesungguhnya merupakan instansi yang membentengi para elit politik dari dosa-dosa politisnya. Pada saat para elit politik memisahkan diri dari kontrol religiositas pada saat itu aktivitas politik kehilangan makna dan relevansinya. Politik laksana rangka mati tanpa nafas yang menghidupinya.

Keadaan ini telah terpola dalam sikap dan tindakan para elit politik dan juga dalam aneka kebijakan politik, dimana muatan religiositas telah dikalahkan oleh nafsu uang dan kuasa. Politik yang kehilangan muatan religiositasnya akan jatuh ke dalam politik dengan mekanisme mengangkangi unsur kebenaran, keadilan, kesejahteraan bersama dan kesamaan hak, yang sesungguhnya menjadi tolok ukur legitimasi aktivitas politik. Karena itu perlu digarisbawahi 2 (dua) hal yang penting yakni hubungan antara politik dengan religiositas (iman) dan perlunya etika politik.

\subsection{Hubungan Politik dan Religiositas (Iman)}

Politik tidak dilaksanakan oleh manusia dalam kekosongan eksistensi tetapi dalam kepenuhan eksistensinya. Salah satu aspek yang melekat kuat dalam diri manusia adalah aspek iman. Pada titik ini ada hubungan yang erat antara politik dan iman. Hubungan antara iman dan politik adalah hubungan keterlibatan eksistensial dialektis non-reduktif. ${ }^{8}$ Hubungan ini di satu pihak menempatkan iman pada level yang tinggi dari politik karena memiliki fungsi kritis terhadap politik dan di lain pihak level yang lebih tinggi ini hanya berarti sejauh terwujud pada level yang lebih rendah. Dengan demikian keduanya akan saling mempengaruhi dan memberi makna jika iman dihayati dengan penuh rasa tanggung jawab maka iman itu akan terungkap di dalam tatanan politik dan tatanan lainnya, sementara politik merupakan salah satu dari bidang kehidupan tempat buah-buah iman harus dibuktikan. ${ }^{9}$

\subsection{Etika Politik}

Etika lebih dipahami sebagai refleksi tentang bagaimana melakukan yang baik dan benar. Dalam konteks politik, tujuan politik sendiri sudah mengandung nilai etis yakni bagaimana mewujudkan kepentingan umum pada semua jenjang dengan penuh tanggung jawab karena berhubungan dengan penghargaan atas martabat manusia.

Tetapi perlu diingat bahwa bukan hanya untuk mencapai tujuan saja tetapi juga jalan yang ditempuh, sarana yang dikerahkan dan cara-cara yang dipakai untuk mencapai tujuan itu tidak boleh dengan jalan pintas tetapi juga berdimensi etis. Dengan demikian etika politik selalu mempertanyakan bagaimana kekuasaan harus ditangani supaya tetap fokus pada penghargaan atas martabat manusia. Dalam konteks Indonesia dengan rupa-rupa kemajemukannya etika politik harus diletakkan dalam kerangka pengakuan Pancasila sebagai satu-satunya azas dalam hidup bermasyarakat, berbangsa dan bernegara. Karena itu bagi semua golongan agama, dasar ketuhanan yang telah diakui menurunkan suatu etika bernegara yang tinggi serentak mandat yang harus dipertanggungjawabkan. ${ }^{10}$

\footnotetext{
${ }^{8}$ Luisi Pi, Menentukan Pilihan Politis (Yogyakarta: Kanisius, 2009), hlm. 34.

${ }^{9}$ John Boylon, Kebebasan Berserikat bagi imam Diosesan (Yayasan Pustaka Nusatama, 2004), hlm. 87.

${ }^{10}$ Pit Go, Peranserta Orang Katolik Dalam Politik (Malang: Dioma, 1990), hlm. 11-12.
} 


\section{PENUTUP}

Politik yang berlandaskan pada religiositas akan berpengaruh pada perubahan tampilan bahasa politik dan perubahan orientasi dasar dalam berpolitik. Bahasa permusuhan akan berubah menjadi bahasa persaudaraan, bahasa kekuasaan berubah menjadi bahasa pengabdian, bahasa superioritas berubah menjadi bahasa solidaritas, bahasa arogansi berubah menjadi bahasa toleransi, bahasa eksklusif menjadi bahasa inklusif. Bahasa monolog menjadi bahasa dialog.

Dengan bahasa-bahasa baru seperti akan tercipta dunia politik dan elit politik yang berintegritas dan sekaligus tercipta arus komunikasi politik yang positif dan konstruktif, sehingga aktivitas politik menjadi aktivitas yag bermartabat dengan ciri utama mengubah benturan niat dan kepentingan serta kepekatan nafsu untuk menguasai, menjadi langka kerja sama yang berorientasi pada maksimalisasi aksi rekonsiliasi dan mimimalisasi aksi kekerasan yang dapat meruntuhkan bangunan kehidupan berbangsa dan bernegara.

\section{Daftar Kepustakaan}

Bagus, Lorens. 1996. Kamus Filsafat. Jakarta: Gramedia.

Boylon, John. 2004. Kebebasan Berserikat bagi imam Diosesan. Yayasan Pustaka Nusatama.

Go, Pit. 1990. Peranserta Orang Katolik Dalam Politik. Malang: Dioma. 2004. Etos dan Moralitas Politik. Yogyakarta: Kanisius.

Kieser B. 2001. Agama dan tantangan Ketulusan: Tulus seperti Merpati dan Cerdik Seperti Ular. Yogyakarta: Kanisius.

Mardi, Prasetya. 2000. Unsur-unsur Hakiki dalam Pembinaan. Yogyakarta: Kanisius.

Pi, Luisi. 1990. Menentukan Pilihan Politis. Yogyakarta: Kanisius.

Sapienza Piero. 2009. La Politica che non C'e, Da Cittadini attivi nella Pollis. Vaticana: Libreria Editrice.

Sutrisno, Muji. 2001. Humanisme, Krisis, Humanisasi. Jakarta: Obor. 2004. Ide-Ide Pencerahan. Jakarta: Obor. 